\title{
Role of hyperinsulinemia on hepatic insulin receptor concentration and autophosphorylation in the presence of high growth hormone levels in transgenic mice overexpressing growth hormone gene
}

\author{
F P Dominici, A Balbis, A Bartke ${ }^{\mathbf{1}}$ and D Turyn \\ Instituto de Química y Fisicoquímica Biológicas (UBA-CONICET), Facultad de Farmacia y Bioquímica, Junin 956, (1113) Buenos Aires, Argentina and \\ ${ }^{1}$ Department of Physiology, School of Medicine, Southern Illinois University, Carbondale, Illinois 62901-6512, USA \\ (Requests for offprints should be addressed to A Bartke)
}

\begin{abstract}
Overexpression of bovine growth hormone $(\mathrm{bGH})$ in transgenic (PEPCK-bGH) mice induces resistance to insulin, which is compensated by a major increase in insulin levels. In these animals, hepatic insulin receptors (InsRs) are downregulated while tyrosine kinase activity of wheat germ agglutinin (WGA)-purified InsRs towards exogenous substrates is unexpectedly increased. By normalizing insulinemia, we attempted to determine whether the alterations detected in the early steps of insulin signal transduction are due to exposure to chronically high $\mathrm{GH}$ levels or are secondary to hyperinsulinemia. Transgenic PEPCK-bGH animals were treated with a single intraperitoneal administration of streptozotocin (STZ) or were deprived of food for $48 \mathrm{~h}$, to normalize insulin levels. Both fasting and STZ treatment were effective in reducing insulin blood levels to control values or below, while GH levels remained unchanged (STZ treatment) or increased (fasted animals). In the liver of untreated transgenic mice, the number of InsRs as determined by ${ }^{125}$ I-insulin binding was significantly diminished $(65 \pm 5 \%$ and $60 \pm 6 \%$ of normal values in microsomes and solubilized membranes respectively; $P<0 \cdot 01$ vs control mice). In treated transgenic mice, the number of InsRs increased to values similar to or slightly higher than those found in normal control mice (STZ-treated: $139 \pm 26 \%$ and $126 \pm 8 \%$; fasted: $128 \pm 5 \%(P<0 \cdot 05)$ and $102 \pm 1 \cdot 5 \%$, for micro-
\end{abstract}

somes and solubilized membranes respectively). Neither treatment altered InsR affinity. InsR concentration in liver as determined by immunoblotting using an antibody against the $\beta$-subunit of the insulin receptor was found to be reduced in transgenic mice ( $69 \pm 3 \%$ of normal values, $P<0 \cdot 001)$ and was normalized after both STZ treatment $(105 \pm 4 \%)$ and fasting $(109 \pm 4 \%)$. Insulin-stimulated autophosphorylation activity of InsRs in transgenic mice was increased $(154 \pm 13 \%, P<0 \cdot 01$ compared with the control group), essentially normalized by STZ treatment (96 $\pm 14 \%)$, and reduced by fasting, to below the values measured in normal control mice $(56 \pm 15 \%, P<0 \cdot 05)$.

The potential influence of basal serine/threonine (Ser/ Thr) phosphorylation of the InsR $\beta$-subunit on the regulation of the InsRs from transgenic mice was also investigated. The autophosphorylation activity of WGApurified InsRs from all groups of mice studied was essentially unchanged after dephosphorylation with alkaline phosphatase or mild trypsinization. Consequently, our results suggest that the observed changes in InsR number and autophosphorylation activity in the liver of bGH transgenic mice are directly related to changes in insulin blood levels, and that Ser/Thr phosphorylation is apparently not involved in the regulation of the InsR autophosphorylation activity in this model of insulin resistance.

Journal of Endocrinology (1998) 159, 15-25

\section{Introduction}

Growth hormone $(\mathrm{GH})$ displays a wide array of biological activities which include both mitogenic and metabolic actions. Carbohydrate metabolism is strongly affected by this hormone which can exert both insulin-like and anti-insulin effects which have been described in many different models (Davidson 1987). Insulin-like effects of $\mathrm{GH}$ are transient and can be detected both in vitro and in vivo only in tissues that have had little or no exposure to GH (Davidson 1987). It is generally accepted that the predominant metabolic effects of $\mathrm{GH}$ are those which antagonize insulin action, leading to hyperglycemia, hyperinsulinemia, decreased glucose utilization and increased lipolysis (Davidson 1987). Consequently, a chronic elevation of $\mathrm{GH}$ levels is associated with the development of insulin resistance, which is clearly detected in patients with acromegaly (Hansen et al. 1986) and GHproducing tumors (Moller \& Flier 1991). Although these effects are well known, the exact molecular mechanisms involved in GH-induced insulin resistance are not well defined. 
Insulin binding to the $\alpha$-subunit of the insulin receptor (InsR) leads to autophosphorylation of the receptor $\beta$-subunit on tyrosine residues and activation of its tyrosine kinase activity towards endogenous substrates (White \& Kahn 1994). These events are essential for signal transmission and consequently for insulin action (White \& Kahn 1994). We have recently reported a reduction in the number of InsRs in the liver of transgenic mice overexpressing bovine (b) $\mathrm{GH}$ and concluded that this decrease might be a factor involved in the state of insulin resistance in these animals. Surprisingly, tyrosine kinase activity of liver InsRs from these transgenic mice was found to be significantly increased (Balbis et al. 1996).

Here we report a study performed in GH transgenic mice in which the abnormally high plasma insulin levels had been lowered to normal values by either a $48-\mathrm{h}$ fast or streptozotocin administration, without decreasing the high $\mathrm{GH}$ levels. Our purpose was to determine if the abnormalities observed in the insulin binding and tyrosine kinase activity in the liver of transgenic mice are secondary to hyperinsulinemia, or can be ascribed to prolonged exposure to elevated plasma GH levels.

Along with phosphorylation at tyrosine residues, phosphorylation at serine/threonine (Ser/Thr) residues of the InsR is also detected (Takayama et al. 1984, Pillay et al. 1991). Various lines of evidence indicate that the extent of Ser/Thr phosphorylation may modulate the receptor function (Takayama et al. 1988, Karasik et al. 1990). Some of the phosphorylation sites putatively involved in this regulation are within the $\mathrm{COOH}$-terminal region of the InsR $\beta$-subunit (Lewis et al. 1990, Coghlan et al. 1994), although phosphorylation at serine residues located outside that region may also be implicated in this regulatory process (Strack et al. 1997). Dissimilar results were obtained when dephosphorylation with alkaline phosphatase and mild trypsinization of the InsR were used to assess the influence of Ser/Thr phosphorylation on autophosphorylation and tyrosine kinase activity of the InsR in insulinresistant models (Karasik et al. 1990, Ruiz et al. 1992, Martinez et al. 1995).

To characterize further the regulation of the InsR in this model, in the present study we measured InsR autophosphorylation activity in the liver of GH-transgenic mice after both alkaline phosphatase treatment and mild trypsinization.

\section{Materials and Methods}

\section{Chemicals}

Porcine insulin, Tosyl-L-phenlaline chloromethyl ketone (TPCK)-treated trypsin, polyethylene glycol, HEPES, Tris- $\mathrm{HCl}$, wheat germ agglutinin (WGA)-Sepharose, Triton X-100, ATP, phenylmethylsulfonyl fluoride (PMSF), sodium ortho-vanadate, di-sodium phenylphosphate, N-acetyl-D-glucosamine, streptozotocin (STZ), aprotinin, bovine serum albumin, alkaline phosphatase and Inmobilon $\mathrm{P}$ membranes (Millipore) were obtained from Sigma Chemical Co. (St Louis, MO, USA). $\mathrm{Na}^{125} \mathrm{I}$ and $\left[\gamma_{-}{ }^{32} \mathrm{P}\right] \mathrm{ATP}$ were purchased from Du Pont-NEN (Boston, MA, USA). Affigel-10 and electrophoresis supplies were purchased from Bio-Rad (Richmond, CA, USA). Sephadex G-50 and protein A-sepharose 6MB were from Pharmacia (Uppsala, Sweden). ${ }^{125}$ I-Protein A was purchased from ICN Biomedicals (Costa Mesa, CA, USA). Anti-insulin receptor $\beta$-subunit polyclonal antibody and anti-phosphotyrosine monoclonal antibody (PY20) were purchased from Transduction Laboratories (Lexington, KY, USA). All other reagents were of analytical grade.

\section{Animals}

Female transgenic mice and their normal female siblings used in this work were derived from animals kindly provided by Dr Thomas E Wagner and Jeung S Yun (Ohio University, USA). These animals were originally produced by microinjection of the $\mathrm{bGH}$ gene fused to the control sequences of the rat phosphoenolpyruvate carboxykinase gene (PEPCK-bGH) into the pronuclei of fertilized mouse eggs (McGrane et al. 1988). The hemizygous transgenic mice used in the present study were derived from a founder male with approximately 25 copies of the hybrid gene, and were produced by mating transgenic males with normal $\mathrm{C} 57 \mathrm{BL} / 6 \times \mathrm{C} 3 \mathrm{H} \mathrm{F}_{1}$ hybrid females purchased from the Jackson Laboratory (Bar Harbour, ME, USA). These matings produced approximately equal numbers of transgenic and normal progeny (used as controls). Transgenic animals had markedly accelerated postweaning growth, leading to a significant increase in body weight at the age of $3-5$ months when the mice were used. Body weights of the mice used for the present study are shown in Table 1 . The animals were housed 3-5 per cage in a room with controlled light (12 h light/day) and temperature $\left(22 \pm 2{ }^{\circ} \mathrm{C}\right)$ with free access to food (Lab Diet, Formulab 5008 containing a minimum of 23\% protein, $6.5 \%$ fat and a maximum of $4 \%$ fiber; PMI Feeds, Inc., St Louis, MO, USA) and tap water.

\section{Streptozotocin treatment}

Insulin-dependent diabetes mellitus in PEPCK-bGH transgenic mice was induced by a single intraperitoneal injection of STZ $(350 \mathrm{mg} / \mathrm{kg})$ dissolved in citrate buffer $(\mathrm{pH} 45)$. Mice that did not respond with hyperglycemia were excluded from the analysis; those with fasting glucose levels above $450 \mathrm{mg} / \mathrm{dl}$ were used in the present study.

Animals were handled daily to record body weight and health. At eight days after the injection of STZ, animals were fasted overnight, bled by cardiac puncture under ether anesthesia and killed by cervical dislocation. Plasma 
was separated by centrifugation and stored at $-20{ }^{\circ} \mathrm{C}$ until further use. Livers were removed and snap frozen and stored at $-70{ }^{\circ} \mathrm{C}$.

\section{Fasting}

A group of PEPCK-bGH mice were fasted for $48 \mathrm{~h}$ with free access to water, and thereafter were anesthetized, bled, and killed. Plasma and liver were stored frozen $\left(-20{ }^{\circ} \mathrm{C}\right.$ and $-70{ }^{\circ} \mathrm{C}$ respectively) for subsequent assays.

\section{Insulin iodination}

Iodination and purification of porcine insulin were performed as previously described (Balbis et al. 1992).

\section{Hormone radioimmunoassays}

Mouse GH (mGH) and bovine GH (bGH) levels were determined by previously described radioimmunoassays (Sotelo et al. 1993). Fasting insulin levels were measured using a solid phase radioimmunoassay kit (Coat-A-Count) purchased from Diagnostic Products Inc. (Los Angeles, CA, USA).

\section{Receptor preparation}

Preparation of a microsomal fraction containing liver plasma membranes was performed using a previously described procedure (Kadowaki et al. 1984) with some modifications. Inhibitors of phosphatases were added to the preparation buffer to preserve the basal phosphorylation of the InsRs. Its final composition was $50 \mathrm{mM}$ Tris- $\mathrm{HCl}$ ( $\mathrm{pH} 7 \cdot 6$ ), 0.25 $\mathrm{M}$ sucrose, $1 \mathrm{mM}$ PMSF, 0.5\% aprotinin, $30 \mathrm{mM}$ sodium pyrophosphate $\left(\mathrm{Na}_{4} \mathrm{P}_{2} \mathrm{O}_{7}\right)$, $1 \mathrm{mM}$ sodium vanadate $\left(\mathrm{Na}_{3} \mathrm{VO}_{2}\right)$ and $10 \mathrm{mM}$ sodium fluoride $(\mathrm{NaF})$ (buffer $\mathrm{A})$. To remove bound endogenous insulin from receptors, after the ultracentrifugation step pellets were resuspended in buffer A without sucrose at $\mathrm{pH} 5.5$ and incubated for $30 \mathrm{~min}$ at $4{ }^{\circ} \mathrm{C}$. After that period, $\mathrm{pH}$ was raised to $7 \cdot 6$ and the membrane suspension was centrifuged again for $90 \mathrm{~min}$ at $100000 \mathrm{~g}$. The resulting pellet was kept at $-70{ }^{\circ} \mathrm{C}$ until further use. For microsomes insulin binding assays, pellets were resuspended in $50 \mathrm{mM}$ Tris- $\mathrm{HCl}$ buffer, $\mathrm{pH}$ 7.6. For solubilization, pellets were resuspended in buffer $(50 \mathrm{mM}$ Tris- $\mathrm{HCl} \mathrm{pH}$ 7.6, 1\% Triton X-100, $1 \mathrm{mM}$ PMSF, $0 \cdot 5 \%$ aprotinin, $30 \mathrm{mM} \mathrm{Na}{ }_{4} \mathrm{P}_{2} \mathrm{O}_{7}, 1 \mathrm{mM} \mathrm{Na}_{3} \mathrm{VO}_{4}$ and $10 \mathrm{mM} \mathrm{NaF}$ ), incubated with gentle agitation overnight at $4{ }^{\circ} \mathrm{C}$, and centrifuged for $90 \mathrm{~min}$ at $100000 \mathrm{~g}$. The supernatant (solubilized receptor) was either used for insulin binding assays or loaded onto WGA-Sepharose columns for affinity chromatography purification.

Protein concentration of crude membranes was determined by the Lowry procedure (Lowry et al. 1951), whereas protein content of solubilized membranes was measured by the Bradford assay (Bradford 1976).

\section{Insulin receptor purification}

Solubilized hepatic membranes were partially purified on WGA-Sepharose columns as described (Bisbis et al. 1993). Solublilized membranes were loaded onto columns containing $2 \mathrm{ml} \mathrm{WGA-Sepharose} \mathrm{and} \mathrm{mixed} \mathrm{end} \mathrm{over} \mathrm{end} \mathrm{for}$ $16 \mathrm{~h}$ at $4{ }^{\circ} \mathrm{C}$. Columns were then washed with $15 \mathrm{ml}$ buffer (50 mM HEPES, pH 7.6, 0.15 M NaCl, $30 \mathrm{mM}$ $\mathrm{Na}_{4} \mathrm{P}_{2} \mathrm{O}_{7}, 1 \mathrm{mM} \mathrm{Na}_{3} \mathrm{VO}_{4}, 10 \mathrm{mM} \mathrm{NaF}$ and $0 \cdot 1 \%$ Triton $\mathrm{X}-100$ ), then with $15 \mathrm{ml}$ of the same buffer without phosphatase inhibitors $\left(\mathrm{Na}_{4} \mathrm{P}_{2} \mathrm{O}_{7}, \mathrm{Na}_{3} \mathrm{VO}_{4}\right.$ and $10 \mathrm{mM}$ $\mathrm{NaF}$ ). Receptors were eluted with $5 \mathrm{ml}$ buffer containing $50 \mathrm{mM}$ Hepes pH 7·6, 0·15 M NaCl, 0·1\% Triton X-100 and $0.3 \mathrm{M} \mathrm{N}$-acetyl glucosamine.

\section{${ }^{125}$ I-Insulin binding assays}

Binding to microsomes, solubilized membranes and WGA-purified InsRs was performed as previously reported (Turyn et al. 1985, Balbis et al. 1996). Binding assays to materials derived from transgenic mice treated with STZ, fasted transgenic mice, untreated transgenic mice, and the corresponding normal controls were performed simultaneously in every case.

\section{Preparation of liver lysates and immunoprecipitation}

Livers which had been kept at $-70{ }^{\circ} \mathrm{C}$ were minced coarsely, and homogenized with a Polytron homogenizer (Kinematica, Littau, Switzerland) in 10 volumes of homogenizing buffer composed of $1 \%$ Triton X-100, $50 \mathrm{mM}$ HEPES (pH 7.4), $100 \mathrm{mM} \mathrm{Na}_{4} \mathrm{P}_{2} \mathrm{O}_{7}, 100 \mathrm{mM} \mathrm{NaF}$, $10 \mathrm{mM}$ EDTA, $10 \mathrm{mM} \mathrm{Na} \mathrm{VO}_{4}, 2 \mathrm{mM}$ PMSF and $0.1 \mathrm{mg} / \mathrm{ml}$ aprotinin. The extracts were centrifuged at 30000 r.p.m. at $4{ }^{\circ} \mathrm{C}$ in a Beckman 90 Ti rotor for $60 \mathrm{~min}$ to remove insoluble material and InsRs were immunoprecipitated from $7.5 \mathrm{mg}$ supernatant protein using $4 \mu \mathrm{g}$ of a polyclonal antibody against the insulin receptor $\beta$-subunit. The immune complexes were collected with protein A-sepharose and were washed three times with $50 \mathrm{mM}$ Tris ( $\mathrm{pH} \mathrm{7 \cdot 4),2} \mathrm{mM} \mathrm{Na}_{3} \mathrm{VO}_{4}$ and $0 \cdot 1 \%$ Triton $\mathrm{X}-100$. After washing, the pellets were resuspended in $60 \mu \mathrm{l}$ twofold concentrated Laemmli sample buffer (Laemmli 1970) and boiled for $5 \mathrm{~min}$.

\section{Immunoblotting}

Equal volumes of the samples were subjected to SDSPAGE (6\% acrylamide) in a Bio-Rad miniature slab gel apparatus. $M_{\mathrm{r}}$ standards used were myosin $(205 \mathrm{kDa})$, $\beta$-galactosidase (116 kDa), phosphorylase b (97 kDa), BSA $(66 \mathrm{kDa})$ and ovalbumin $(45 \mathrm{kDa})$. Electrotransfer of proteins from the gel to Immobilon $\mathrm{P}$ membranes was 
performed at $110 \mathrm{~V}$ for $2 \mathrm{~h}$ in a Bio-Rad miniature transfer apparatus (Mini-Protean, Bio-Rad Laboratories) as described by Towbin et al. (1979) but with 0.02\% SDS addded to the transfer buffer. Non-specific protein binding was reduced by preincubating the membranes overnight at $4{ }^{\circ} \mathrm{C}$ in blocking buffer $(5 \%$ non-fat dried milk, $10 \mathrm{mM}$ Tris, $150 \mathrm{mM} \mathrm{NaCl}$, and $0.02 \%$ Tween 20). For phosphotyrosine detection, milk was replaced by $3 \%$ BSA. The membranes were incubated for $2 \mathrm{~h}$ at $22^{\circ} \mathrm{C}$ with an anti-insulin receptor antibody $(1: 250)$ or with an antiphosphotyrosine antibody $(1: 1000)$, diluted in the corresponding blocking buffer and washed for 20 min with the blocking buffer without milk or BSA. The membranes were then incubated with $2-3 \mu \mathrm{Ci}{ }^{125}$ I-Protein A $(30 \mu \mathrm{Ci} / \mu \mathrm{g})$ in $10 \mathrm{ml}$ blocking buffer for $1 \mathrm{~h}$ at $22{ }^{\circ} \mathrm{C}$ and washed, again as described, for $40 \mathrm{~min} .{ }^{125}$ I-Protein A bound to anti-insulin receptor or anti-phosphotyrosine antibodies was detected by autoradiography using preflashed Kodak XAR film with Cronex Lightning Plus intensifying screens at $-70{ }^{\circ} \mathrm{C}$ for $12-48 \mathrm{~h}$. Band intensities were quantitated by optical densitometry of the developed autoradiograms in a Shimadzu scanner CS-930.

\section{Autophosphorylation of WGA-purified receptors}

WGA-purified InsRs $(30 \mu \mathrm{l})$ were preincubated overnight at $4{ }^{\circ} \mathrm{C}$, in the absence or presence of $1 \mu \mathrm{M}$ insulin. Autophosphorylation was initiated by addition of $\left[\gamma^{32} \mathrm{P}\right] \mathrm{ATP}$ $(25 \mu \mathrm{M}, 8 \mu \mathrm{Ci})$ in buffer $(50 \mathrm{mM}$ HEPES, $\mathrm{pH} 7.6$ containing $\mathrm{MnCl}_{2}$ and $\mathrm{MgCl}_{2}$ (final concentrations: $4 \mathrm{mM}$ and $12 \mathrm{mM}$ respectively), in a final volume of $50 \mu \mathrm{l}$. After 5 min at $22{ }^{\circ} \mathrm{C}$, the reaction was stopped by addition of $50 \mu \mathrm{l}$ twofold concentrated Laemmli sample buffer, and subsequently heated for $3 \mathrm{~min}$ at $100{ }^{\circ} \mathrm{C}$. InsR $\beta$-subunits were resolved by SDS-PAGE in $7 \cdot 5 \%$ gels. Samples from each group of animals were run in duplicate. After autoradiography, labeled bands were quantified by densitometry as described above. Autophosphorylation activity of each receptor preparation was normalized by insulin binding activity.

\section{Treatment of purified insulin receptors with} alkaline phosphatase

This procedure was performed as previously described (Karasik et al. 1990, Martinez et al. 1995). Briefly, alkaline phosphatase was immobilized to Affigel-10 (Bio-Rad) following the manufacturer's instructions. WGA-purified InsRs from each group were incubated for $1 \mathrm{~h}$ at $4{ }^{\circ} \mathrm{C}$ with 500 units of the immobilized enzyme. Samples were centrifuged, and the supernatants were used in phosphorylation assays as detailed. Control samples were prepared by treatment with immobilized alkaline phosphatase which had formerly been inactivated by boiling for $30 \mathrm{~min}$. To evaluate the activity of the immobilized enzyme against phosphoproteins, a positive control was performed using WGA-purified InsRs from normal mice. This material was incubated with or without insulin $(1 \mu \mathrm{M})$ and autophosphorylation was initiated as described above but using non-radioactive ATP instead. Equal volumes of insulin-stimulated InsRs were then incubated with active or heat-inactivated immobilized alkaline phosphatase. Samples were immunoprecipitated with an anti-insulin receptor $\beta$-subunit antibody as described above. Tyrosine phosphorylation in the immunoprecipitates was detected by immunoblotting using an anti-phosphotyrosine antibody. Visualization of immunocomplexes was performed by incubation with ${ }^{125}$ I-Protein A and autoradiography as described above.

\section{Mild trypsinization of the insulin receptor}

Mild tryptic digestion of purified receptors was performed as described (Karasik et al. 1990, Martinez et al. 1995). WGA-purified receptors from each group were treated with TPCK-treated trypsin $(10 \mu \mathrm{g} / \mathrm{ml})$ for $1 \mathrm{~min}$ at $22{ }^{\circ} \mathrm{C}$. Digestion was terminated by addition of aprotinin to a final concentration of $100 \mu \mathrm{g} / \mathrm{ml}$. Insulin-induced autophosphorylation of treated receptors was performed as described above.

Results from binding and autophosphorylation assays are expressed as means \pm S.E.M. Student's $t$-test was used for all analysis of binding data and autophosphorylation activity. The level of significance used was $P<0 \cdot 05$.

\section{Results}

\section{$\mathrm{GH}$, insulin and glucose levels}

Insulin levels in transgenic mice were markedly increased, while glucose levels were not significantly altered, as was expected from previous studies (Valera et al. 1993, Table 1). Treatment of transgenic mice with STZ resulted in a significant increase in glucose levels (three- to fourfold), whereas the insulin levels decreased to values close to those detected in control mice (Table 1). Insulin levels in serum of fasted mice decreased markedly and were not significantly different from those measured in control animals, while glucose levels did not change (Table 1). Serum concentrations of $\mathrm{GH}$ in transgenic animals ranged from approximately 500 to $900 \mathrm{ng} / \mathrm{ml}$. In transgenic mice treated with STZ or fasted for $48 \mathrm{~h}$, bGH levels were not significantly different from those detected in untreated transgenic mice (Table 1).

\section{Insulin binding}

Figure 1a shows that specific ${ }^{125}$ I-insulin binding to liver microsomes from transgenic mice was significantly diminished in comparison to that of control mice (measured values were $65 \pm 5 \%, n=4, P<0 \cdot 01$ vs control mice), in 
Table 1 Body weight, plasma glucose, plasma insulin and serum GH levels in the animals used in the present study. Data are expressed as means \pm S.E.M., and $n$ represents the number of animals in each group

\begin{tabular}{|c|c|c|c|c|}
\hline & Control & Transgenic & T-STZ & T-fasted \\
\hline$n$ & 9 & 11 & 11 & 9 \\
\hline Body weight (g) & $31 \pm 5$ & $44 \pm 6^{*}$ & $34 \pm 3$ & $44 \pm 5^{*}$ \\
\hline Glucose $(\mathrm{mg} / \mathrm{dl})$ & $158 \pm 23$ & $148 \pm 19$ & $518 \pm 55^{*}$ & $151 \pm 17$ \\
\hline Insulin $(\mu \mathrm{IU} / \mathrm{ml})$ & $15 \pm 7$ & $97 \pm 28^{*}$ & $18 \pm 9$ & $11 \pm 7$ \\
\hline $\mathrm{GH}(\mathrm{ng} / \mathrm{ml})$ & $15 \pm 8$ & $773 \pm 208^{*}$ & $542 \pm 134^{*}$ & $1530 \pm 692 *$ \\
\hline
\end{tabular}

$* P<0 \cdot 01$ vs control mice.

T-STZ, transgenic STZ-treated; T-fasted, transgenic fasted mice. GH data represent mouse GH in normal (control) mice, and bovine $\mathrm{GH}$ in transgenic mice.

agreement with our previously reported results (Balbis et al. 1992, 1996). This marked reduction in insulin binding activity to hepatic InsRs in transgenic mice was corrected either by STZ treatment $(139 \pm 26 \%$ of values measured in normal mice, $n=4$ ) or by a 48 -h fast
(128 $\pm 5 \%, n=4 ; P<0 \cdot 05$ vs control; $P<0 \cdot 01$ vs transgenic) (Fig. 1a). The differences between normal controls and treated and untreated transgenic mice were due to changes in the InsR number, since the competition curves for InsR binding from liver microsomes were similar for all four a

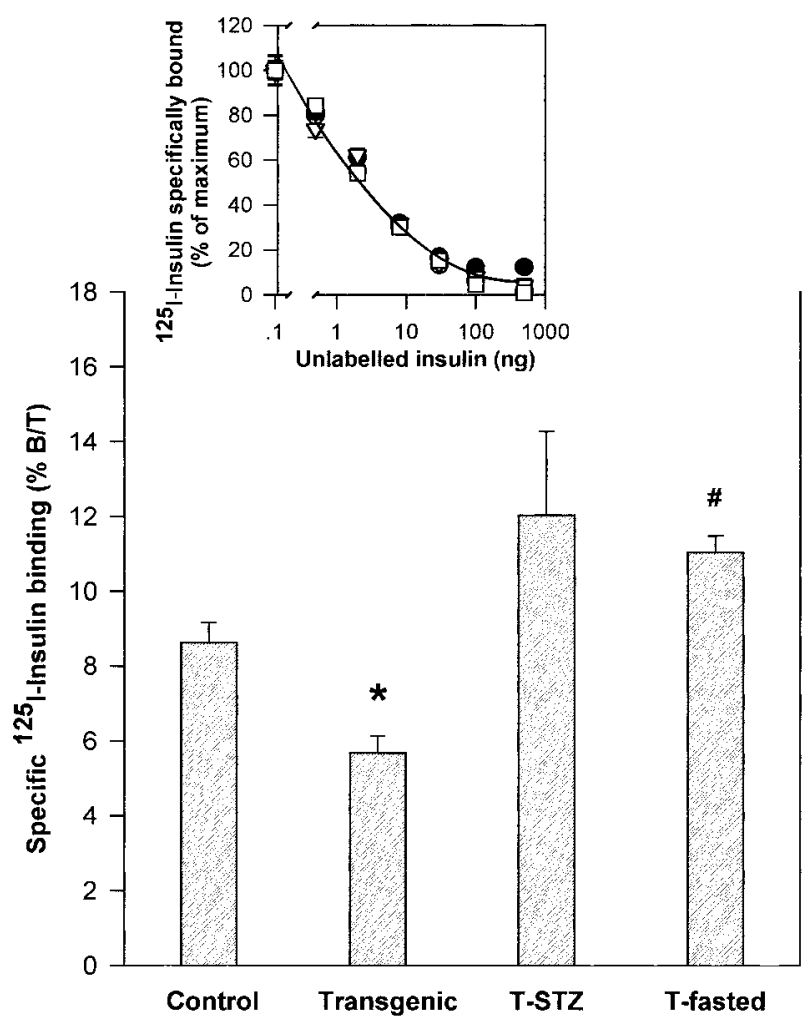

b

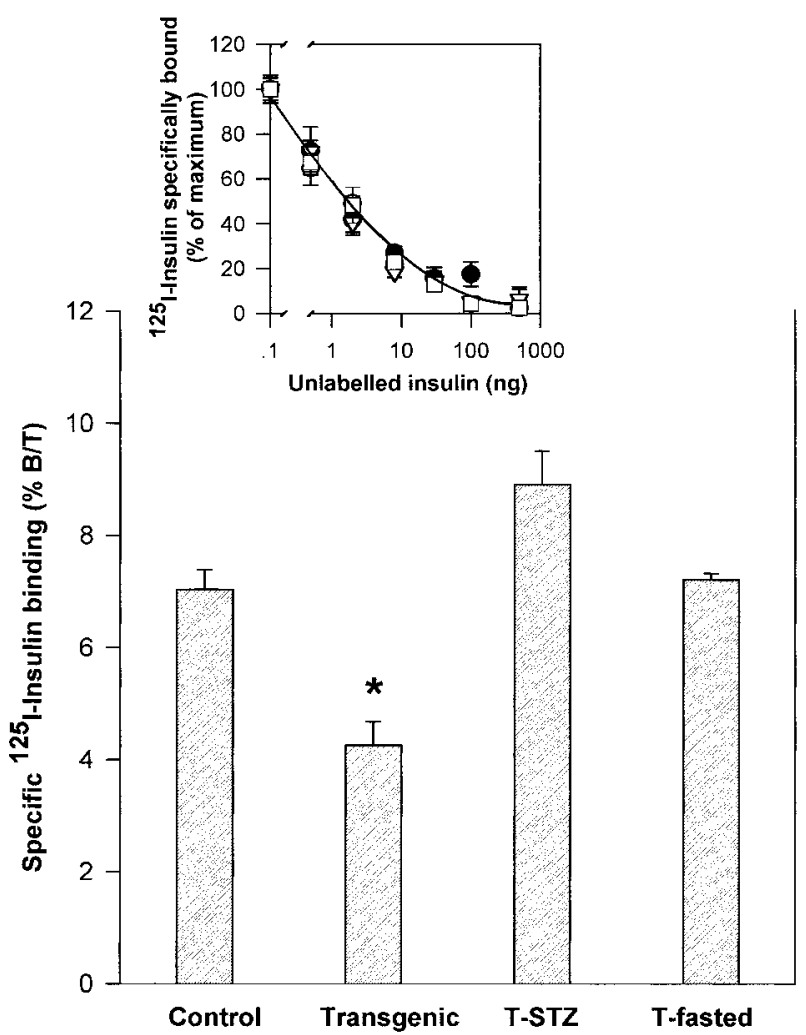

Figure 1 Specific insulin binding to (a) microsomes and (b) solubilized membranes prepared from liver of control, transgenic, transgenic streptozotocin-treated (T-STZ), and transgenic fasted (T-fasted) mice. Total and non-specific (in the presence of $20 \mu \mathrm{g} / \mathrm{ml}$ insulin) insulin binding was measured after incubation for $16 \mathrm{~h}$ at $4{ }^{\circ} \mathrm{C}$. Specific insulin binding was calculated as insulin bound/total $\times 100(\mathrm{~B} / \mathrm{T}) \mathrm{using}$ $30 \mu \mathrm{g}$ microsome protein (a) or $10 \mu \mathrm{g}$ solubilized membrane protein (b). Competitive inhibition binding of ${ }^{125}$ I-insulin to microsomes from normal (control) $(\bigcirc)$, transgenic $(-)$, T-STZ $(\nabla)$, and T-fasted $(\square)$ mice are shown in the inserts. Specific ${ }^{125}$ I-insulin binding was measured in four separate preparations, each performed in triplicate, and expressed as means \pm S.E.M. For each experiment, livers from 2-4 mice from each group were pooled. $\# P<0 \cdot 05$ vs control mice; ${ }^{*} P<0 \cdot 01$ vs control mice. 
groups of animals studied (Fig. 1a, insert), indicating similar affinity $\left(K_{\mathrm{d}}\right.$ of high affinity binding sites was approximately $2 \mathrm{nM}$ in all groups; data not shown).

In the present study we have also determined the total content of InsRs present in membranes from liver of these animals. This was performed by measuring insulin binding to detergent-solubilized membranes. In all cases, insulin binding was higher than that obtained using microsomes (by approximately 150\%). However, similar to the results obtained using microsomes, the specific insulin binding to solubilized membranes in transgenic mice was reduced $(60 \pm 6 \%, n=4, P<0 \cdot 01$ vs normal controls), while in treated transgenic animals (STZ-treated or fasted) insulin binding was similar or slightly higher than the values found in control mice. Insulin binding in STZ-treated mice was $126 \pm 8 \%(n=4)$ and in fasted mice was $102 \pm 1 \cdot 5 \%(n=4)$ (Fig. 1b).

Competition curves for InsR binding were similar in all groups (Fig. 1b, insert). Scatchard analysis of data revealed that the $K_{\mathrm{d}}$ was similar in all four groups studied $\left(K_{\mathrm{d}}\right.$ of high affinity binding sites was approximately $2 \mathrm{nM}$, data not shown).

\section{Ins $R$ concentration}

The abundance of InsRs in liver was assessed by immunoprecipitation and immunoblotting using an antibody to the InsR $\beta$-subunit. There was a significant decrease in the levels of hepatic InsRs in GH-transgenic mice compared with normal mice $(69 \pm 3 \%, n=6, P<0 \cdot 001$; Fig. 2$)$. After normalization of insulin levels by STZ treatment or fasting, the concentration of InsRs increased to values which did not differ from those detected in control mice. InsR concentration expressed as a percentage of that measured in liver of control mice was $105 \pm 4 \%(n=6)$ and $109 \pm 4 \%(n=6)$ in STZ-treated and fasted transgenic mice respectively (Fig. 2).

\section{Ins $R$ autophosphorylation}

Autophosphorylation of InsRs was evaluated using WGApurified receptors from normal as well as untreated and treated transgenic mice. The level of phosphorylation was normalized to the amount of InsRs according to the ${ }^{125}$ I-insulin binding activity present in each preparation. Comparison of the activities was performed setting insulinstimulated InsR autophosphorylation activity of control mice at $100 \%$. As shown in Fig. 3, insulin-stimulated autophosphorylation of the $\beta$-subunit of the InsR was increased in transgenic mice as compared with the normal control mice $(154 \pm 13 \%, n=4, P<0 \cdot 01)$. Insulinstimulated autophosphorylation of purified InsRs derived from liver of transgenic STZ-treated and transgenic fasted mice was reduced in comparison to the values measured in untreated transgenic mice. There were no significant differences in insulin-stimulated autophosphorylation be-
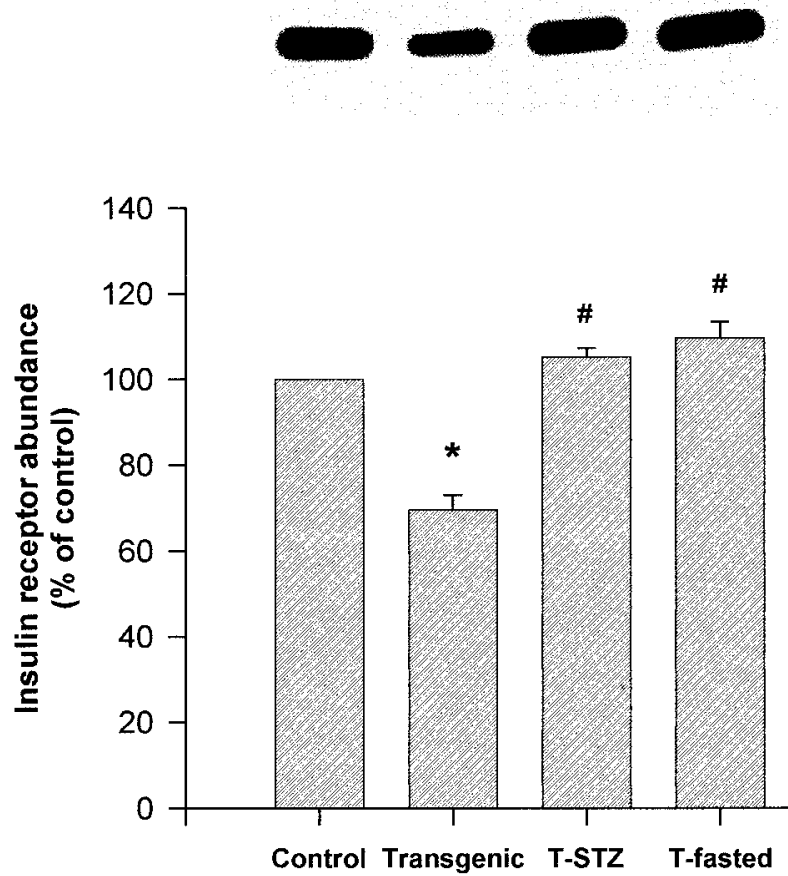

Figure 2 Abundance of InsR $\beta$-subunit in liver of control, transgenic, transgenic STZ-treated (T-STZ), and transgenic fasted (T-fasted) mice. The proteins from the liver were isolated as described in Materials and Methods. After centrifugation, equal amounts of liver protein from the supernatants $(7.5 \mathrm{mg})$ were immunoprecipitated using an antibody to the InsR $\beta$-subunit. The immunoprecipitates were subjected to immunoblot analysis using the same antibody. All groups of animals were studied simultaneously. Bars represent means \pm S.E.M. of six animals. ${ }^{*} P<0.001$ vs control mice; \# not significantly different from control mice. Representative blots are shown above.

tween STZ-treated and normal control mice $(96 \pm 17 \%$, $n=4$ ), while insulin-stimulated autophosphorylation in fasted transgenic mice was significantly lower than that measured in control mice $(56 \pm 15 \%, n=4, P<0 \cdot 05$; Fig. 3 ). In addition, as shown in Fig. 3, basal InsR autophosphorylation was significantly increased in transgenic mice compared with control mice $(279 \pm 19 \%, n=4, P<0 \cdot 01)$. After both STZ treatment and fasting, basal autophosphorylation decreased to values not significantly different from those detected in control mice (Fig. 3).

\section{Autophosphorylation of InsRs after treatment with alkaline phosphatase}

WGA-purified InsRs were incubated with active or inactive immobilized alkaline phosphatase to eliminate pre-existent phosphorylation. After treatment, InsRs were incubated with $\left[\gamma-{ }^{32} \mathrm{P}\right] \mathrm{ATP}$ and $\mathrm{Mn}^{2+}$ in the absence or presence of $1 \mu \mathrm{M}$ insulin to evaluate insulin-dependent autophosphorylation activity. No differences in insulin- 


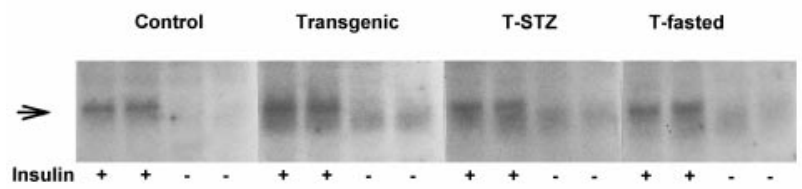

b

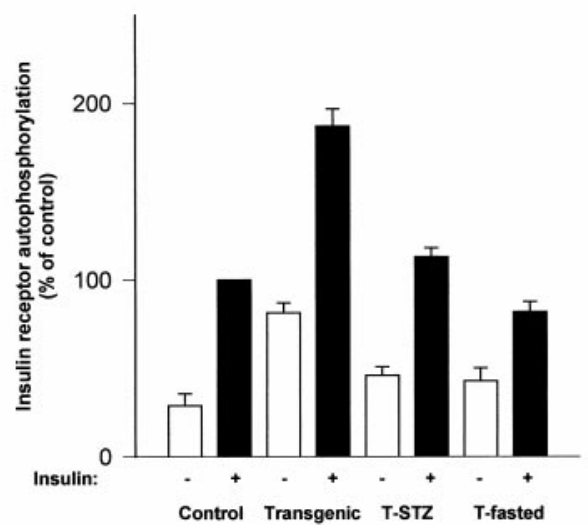

Figure 3 Autophosphorylation of WGA-purified hepatic InsRs from control, transgenic, transgenic streptozotocin-treated (T-STZ) and transgenic-fasted (T-fasted) mice. (a) InsRs were purified from liver on immobilized WGA as described in Materials and Methods. WGA eluates $(30 \mu \mathrm{l})$ were incubated with $0(-)$ or $1 \mu \mathrm{M}(+)$ insulin for $18 \mathrm{~h}$ at $4{ }^{\circ} \mathrm{C}$ and autophosphorylation was performed as described in Materials and Methods. The autoradiogram corresponds to an experiment performed using WGA-purified InsRs with specific insulin binding (expressed as $\% \mathrm{~B} / \mathrm{T}$ per $\mu$ l eluate) of $0.78,0.75,0.65$ and 0.91 for control, untreated, STZ-treated and fasted transgenic mice respectively. Samples were analyzed by SDS-PAGE followed by autoradiography. The autoradiogram is representative of four experiments. The arrow indicates the $95 \mathrm{kDa}$ band. (b) Basal and insulin-induced receptor autophosphorylation. Band intensities corresponding to basal (open bars; ( -$)$ ) and insulin-stimulated (solid bars; (+)) receptors were determined by densitometry. Data were normalized by ${ }^{125}$ I-insulin binding. Comparison of the values was performed by taking the mean value of stimulated control receptor as $100 \%$. Results are expressed as means \pm S.E.M. of four separate experiments performed in duplicate.

induced autophosphorylation were found between receptors that were treated with active and inactive alkaline phosphatase (Fig. 4b,c).

The ability of the immobilized enzyme to remove phosphate groups from phosphoproteins was checked by Western blotting. WGA-purified InsRs from normal mice were incubated with insulin and autophosphorylation was initiated as described in Materials and Methods. However, non-radioactive ATP was used. Phosphorylated InsRs were subsequently incubated with active or heatinactivated immobilized alkaline phosphatase, and the phosphate content from tyrosine groups was quantitated by immunoblotting using anti-phosphotyrosine antibodies. Basal tyrosine phosphorylation was not detectable (Fig. 4a, lane 1). However, it increased greatly after insulin stimulation (Fig. 4a, lane 4). After treatment with the active enzyme, tyrosine phosphorylation was no longer detectable (Fig. 4a, lane 2). As expected, treatment of the insulin-stimulated InsRs with the heat-inactivated enzyme did not significantly alter tyrosine phosphorylation compared with untreated stimulated InsRs (Fig. $4 a$, lanes 3 and 4 respectively).

\section{Autophosphorylation of InsRs after mild trypsinization}

To remove a $10 \mathrm{kDa}$ fragment from the $\mathrm{C}$-terminus of the $\beta$-subunit of the InsR, WGA-purified InsRs from livers of control, as well as untreated, STZ-treated or fasted transgenic mice were treated with trypsin for $1 \mathrm{~min}$ at $22{ }^{\circ} \mathrm{C}$ (Goren et al. 1987). This fragment contains several Ser/ Thr phosphorylation sites which may be involved in the regulation of the autophosphorylation activity of the InsRs (Lewis et al. 1990, Tavare et al. 1991, Coghlan et al. 1994).

We compared trypsin-treated preparations to non trypsin-treated preparations by using the amounts of WGA-purified InsRs containing the same insulin binding activity from each group of animals. Trypsin-treated $\beta$-subunits migrated as a band of $85 \mathrm{kDa}$ (Goren et al. 1987). Removal of the $10 \mathrm{kDa}$ peptide produced no significant changes in the insulin-induced autophosphorylation activity of the receptors as compared with non trypsin-treated InsRs evaluated in parallel (Fig. 5).

\section{Discussion}

The anti-insulin effects of growth hormone on carbohydrates and lipid metabolism have been extensively described (Davidson 1987), but the molecular mechanisms which account for the disorders associated with GH excess remain to be elucidated. Transgenic mice used in the present study have chronic elevation in the circulating concentration of $\mathrm{bGH}$, which results in an elevation of serum insulin levels while plasma glucose levels are not significantly altered (Valera et al. 1993, Table 1). Thus, bGH-transgenic mice appear to provide a useful model for studying insulin resistance induced by a chronic elevation of GH levels.

In previous work, we have reported a significant decrease in the number of hepatic InsRs in transgenic mice with a moderate (Balbis et al. 1992) or a more pronounced increase in plasma GH levels (Balbis et al. 1996). These alterations contribute to insulin resistance but do not explain it completely, indicating that other factors should also be involved in the development of the insulin-resistant state (Balbis et al. 1992, 1996).

In the present work, we attempted to dissociate the effects of hyperinsulinemia from those of high GH levels in order to evaluate the influence of the elevation of each hormone separately on the observed alterations. To achieve this goal, we decided to decrease plasma insulin 
a

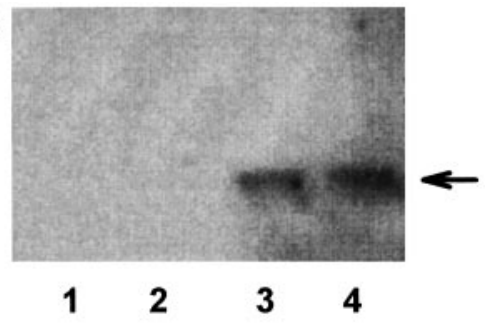

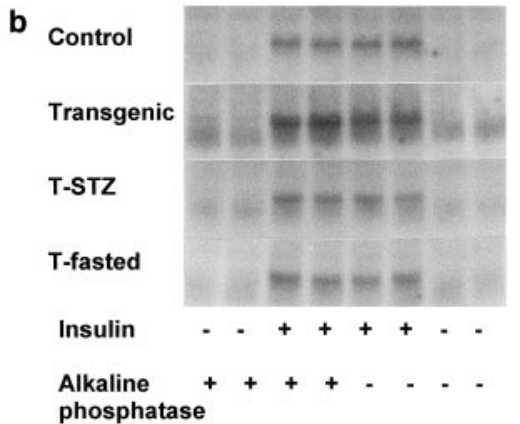

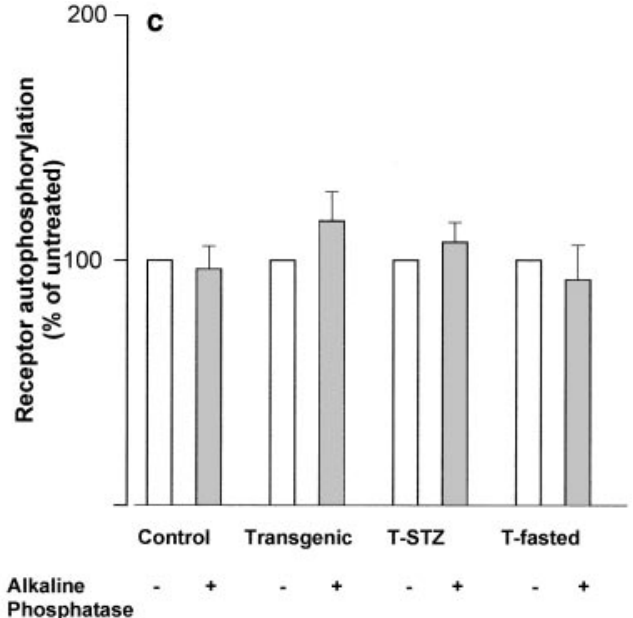

Figure 4 Effect of alkaline phosphatase on autophosphorylation of hepatic InsRs in control, transgenic, transgenic STZ-treated (T-STZ), and transgenic-fasted (T-fasted) mice. (a) Control of the activity of the immobilized enzyme: WGA-purified InsRs from control mice were pre-incubated with (lanes 2, 3, 4) or without (lane 1) insulin $\left(1 \times 10^{-6} \mathrm{M}\right)$, phosphorylated in the presence of $25 \mu \mathrm{M}$ ATP, and treated with active (lane 2) or heat inactivated (lane 3) immobilized alkaline phosphatase as described in Materials and Methods. After immunoprecipitation with an anti-InsR antibody, phosphotyrosine content was determined by immunoblotting using anti-phosphotyrosine antibody. The arrow indicates the InsR $\beta$-subunit. (b) Autoradiograms of the phosphorylated $\beta$-subunits corresponding to the indicated samples.

WGA-purified InsRs were incubated in the presence of active or inactivated alkaline phosphatase-agarose. After $1 \mathrm{~h}$ at $4{ }^{\circ} \mathrm{C}$, samples were centrifuged and the supernatants were used for autophosphorylation assays in the absence $(-)$ or presence $(+)$ of insulin $(1 \mu \mathrm{M})$ as indicated in Materials and Methods. (c) Intensities of bands from the autoradiograms in (b) were quantified by densitometric analysis and specific insulin-stimulated autophosphorylation was calculated as described for Fig. $3 \mathrm{~b}$. The data shown are the means of four determinations \pm S.E.M.

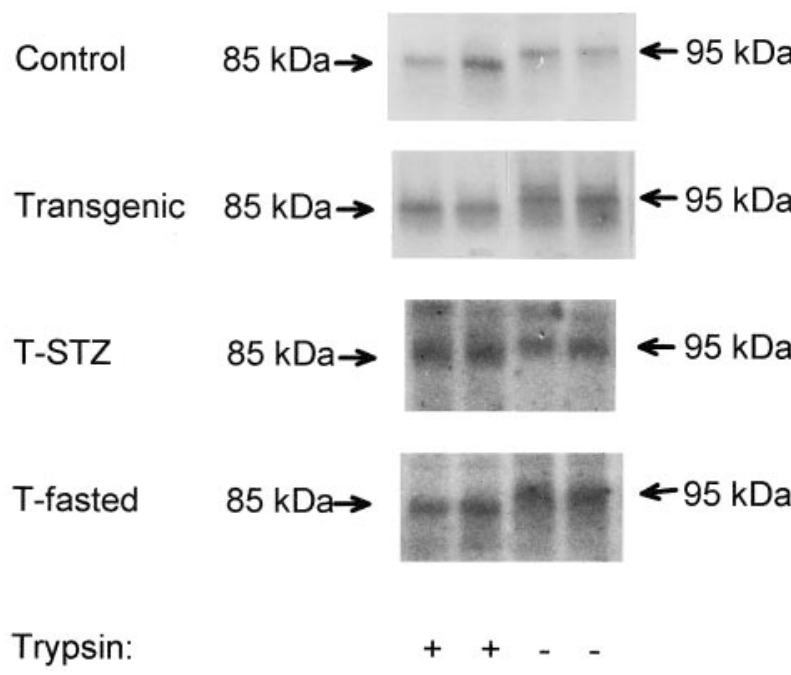

Figure 5 Effect of mild trypsinization on insulin receptor autophosphorylation. WGA-purified InsRs were incubated with trypsin for 1 min at $22{ }^{\circ} \mathrm{C}$ and the reaction was stopped with an excess of a trypsin inhibitor $(100 \mu \mathrm{g} / \mathrm{ml}$ aprotinin). Non-trypsinized InsRs were used as controls. Autophosphorylation was performed as indicated in Materials and Methods. This is a representative experiment which was run in duplicate and was repeated four times using pooled material from two animals from each group in each experiment. Band intensities (calculated as for Fig. 3) did not differ significantly after removal of the 10-kDa fragment (data not shown). Only lanes corresponding to insulin-stimulated receptors are shown. levels to normal values while maintaining plasma $\mathrm{GH}$ levels. We have employed two different methods to decrease plasma insulin levels to values similar to those measured in normal control mice. Treatment of transgenic mice with STZ for 8 days diminished plasma insulin levels to control values, and a 48-h fast had similar effects. Growth hormone levels remained unchanged in STZ-treated mice, and appeared to increase further in fasted transgenic animals.

The content of hepatic insulin receptors which are accessible to their specific ligand was assessed using liver microsomal membranes. In transgenic mice a significant reduction of 35\% was found in insulin binding, compared with normal control mice. In response to the normalization of insulin levels, both groups of treated transgenic mice (STZ-treated and fasted) exhibited a significant increase in insulin binding to liver microsomal membranes when compared with untreated transgenic mice. Insulin binding to liver microsomes did not differ significantly in normal mice and in STZ-treated transgenic mice, but was slightly increased after fasting. Scatchard analysis of the data obtained from competition studies revealed that these changes were due to an increase in the InsR number. These results indicate that the normalization of plasma insulin levels led to a correction in the number of insulin receptors from liver microsomal membranes.

We have also examined the total content of InsRs present in liver microsomal membranes. This procedure 
was performed by measuring insulin binding to membranes that had been solubilized with a non-ionic detergent (Triton X-100). As was previously reported, in every determination, total detergent extractable binding was much higher than that detected in the respective microsomal preparation (by 150\% approximately) (Turyn et al. 1985, Balbis et al. 1996). As anticipated from previous findings, insulin binding was significantly diminished in solubilized membranes from the liver of PEPCK-bGH transgenic mice compared with values detected in normal animals (Balbis et al. 1996).

In concordance with the results obtained with microsomal membranes, when animals were fasted or treated with STZ, insulin binding increased to values similar to or slightly higher than those detected in normal mice, despite the high concentration of circulating GH. To confirm the data obtained from binding assays, InsR concentration in liver was measured by immunoblotting using an antibody against the InsR $\beta$-subunit. Data from these experiments are shown in Fig. 2. When compared with control mice, the levels of hepatic InsRs in GH-transgenic mice were found to be significantly decreased. InsR concentration was $69 \%$ of control values. After normalization of insulin levels by STZ treatment or fasting, the concentration of InsRs increased to values which did not differ from those detected in control mice, thus supporting the data from insulin binding. The present results indicate that elevated insulin levels rather than the high GH levels are responsible for the changes observed in InsR concentration in $\mathrm{GH}$-transgenic mice. They agree with many reports which have established that insulin regulates the concentration of its own receptors. In many physiological and pathological conditions, hyperinsulinemia is associated with reduced concentrations of InsRs. Moreover, in some hypoinsulinemic states InsR numbers were increased (Hepp et al. 1975, Kalant et al. 1984). After fasting or STZ treatment, the levels of InsRs were normalized even though heterologous plasma GH levels remained abnormally high, indicating that the elevation of GH does not affect either insulin binding or the concentration of InsRs in the liver of PEPCK-bGH mice. These observations are consistent with other studies performed in vitro, which have shown that GH does not have a direct influence on insulin binding (Davidson 1987). Therefore, our results support a major role for hyperinsulinemia in the reduction of insulin binding and InsR concentration in the liver of transgenic mice.

Insulin binding is followed by autophosphorylation of the InsR $\beta$-subunit. This event greatly enhances its tyrosine kinase activity towards endogenous substrates, which is considered to be essential for most of insulin's biological effects (White \& Kahn 1994). An impairment in InsR autophosphorylation and tyrosine kinase activity has been detected in many types of insulin resistance (Moller \& Flier 1991, Kahn 1995). In earlier work we have shown a significant increase in the tyrosine kinase activity of the insulin receptor from liver of transgenic mice expressing high levels of bGH (Balbis et al. 1996). As was postulated above for insulin binding, it was of interest to determine whether the alterations in tyrosine kinase activity of the insulin receptor isolated from $\mathrm{GH}$-transgenic mice was a consequence of the increased insulin levels, high GH levels, or both.

Autophosphorylation of the InsRs was examined in treated (STZ or fasted) transgenic, untreated transgenic and normal mice. In agreement with previous studies performed using a synthetic exogenous substrate (Balbis et al. 1996), untreated transgenic mice exhibited a significant increase in insulin-stimulated autophosphorylation activity. In transgenic animals made diabetic by administration of STZ, insulin-stimulated InsR autophosphorylation decreased to values similar to those detected in control mice. After a 48-h fast, InsR autophosphorylation was markedly decreased (below control values) when compared with control transgenic mice. As shown in Fig. 3 , in transgenic animals basal autophosphorylation was also increased, possibly due to chronic exposure to supranormal insulin levels. Both treatments were effective in reducing the basal autophosphorylation activity to values which did not differ significantly from control values (Fig. 3). Similar results were obtained when tyrosine kinase activity was analyzed using an exogenous substrate (data not shown). As for insulin binding and InsR concentration, our results indicate that the increase in autophosphorylation activity of the InsRs in transgenic mice overexpressing GH seems to be related to hyperinsulinemia. The present results agree with studies performed in insulin-resistant obese Zucker rats, which present supranormal tyrosine kinase activity correlated with hyperinsulinemia (Debant et al. 1987, Shemer et al. 1988, Slieker et al. 1990). A polypeptide corresponding to the $\mathrm{N}$-terminus sequence of human GH has been shown to stimulate InsR kinase activity in vitro (Lim et al. 1994). Recently, we have suggested that the high amount of circulating GH could lead to the formation of this fragment of $\mathrm{GH}$ in transgenic mice in vivo, which may account for the activation observed in the InsR kinase activity of these animals (Balbis et al. 1996). Our current results allow us to discard that possibility, because autophosphorylation of the InsRs in treated (STZ and fasted) transgenic mice normalized or decreased below values measured in normal animals in spite of the maintenance of high plasma GH levels (Fig. 3).

It has been reported that Ser/Thr phosphorylation of the InsR $\beta$-subunit is involved in the regulation of the autophosphorylation and tyrosine kinase activity of the receptor (Takayama et al. 1988, Karasik et al. 1990, Dunaif et al. 1995). Although this has not been a consistent observation (Coghlan \& Siddle 1993, Kellerer et al. 1995), no correlation was found between the level of tyrosine kinase activity and the extent of Ser/Thr phosphorylation at specific sites of the InsR (Kellerer et al. 1995). 
As we detected increased basal phosphorylation of the InsRs isolated from livers of PEPCK-bGH mice, we were interested in determining if there was a relationship between the changes in InsR autophosphorylation detected in control transgenic and treated transgenic mice and the basal level of Ser/Thr phosphorylation of the InsR $\beta$-subunit. WGA-purified InsRs were treated with alkaline phosphatase to remove phosphate groups from the residues. We could not detect changes in the activity of InsRs after alkaline phosphatase treatment in any of the groups of mice studied (Fig. 4b,c) even though we checked that the immobilized enzyme was active against phosphoproteins (Fig. 4a). Our results contrast with the findings of Karasik et al. (1990), who reported a fourfold increase in the autophosphorylation activity of WGApurified InsRs from livers of starved rats after phosphatase treatment. In that work, it was postulated that alkaline phosphatase removed phosphate groups from Ser/Thr residues of the InsRs, and that these groups resulted from increased protein kinase $\mathrm{C}$ activity and the consequent decrease in autophosphorylation activity of the InsRs. Although we have not measured protein kinase $\mathrm{C}$ levels in PEPCK-bGH mice it is possible that they were not altered, and thus this mechanism would not apply to this model. In STZ-treated rats, the reduction found in InsR autophosphorylation was not reversed by the treatment (Karasik et al. 1990). Together with our results, this would indicate that this type of regulation would not be a general mechanism of regulation of the InsRs.

Mild trypsinization of the InsRs is known to remove a $10-\mathrm{kDa}$ fragment from the C-terminal tail of the $\beta$-subunit (Goren et al. 1987). This region of the receptor contains Ser/Thr phosphorylation sites which may play a potential regulatory role in insulin receptor tyrosine kinase activity (Lewis et al. 1990, Tavare et al. 1991, Coghlan et al. 1994). It has been reported that the removal of the C-terminus tail of the $\beta$-subunit of the InsR by the above-mentioned procedure reverses the inhibition of insulin-induced autophosphorylation observed in the InsRs of fasted rats (Karasik et al. 1990). In contrast with that report, the results presented in Fig. 5 show that the level of autophosphorylation of the insulin receptors from control, transgenic, and treated transgenic mice remained essentially unchanged after tryptic elimination of the C-terminal domain. Our results agree with those obtained previously in other animal models, such as aged and pregnant rats, where the autophosphorylation activity remained practically unchanged after this kind of treatment (Ruiz et al. 1992, Martinez et al. 1995). Additional evidence for the lack of functional relevance of serine residues located in this region of the InsR was recently provided by site-directed mutagenesis (Strack et al. 1997). The results obtained after alkaline phosphatase and trypsinization of the InsRs from bGH-transgenic mice provide further support for the proposal that Ser/Thr phosphorylation is not involved in the regulation of the InsRs in all forms of insulin resistance (Karasik et al. 1990).

In conclusion, we have evaluated the influence of insulinemia and Ser/Thr phosphorylation on the regulation of the InsR number and autophosphorylation activity in a model of GH-induced insulin resistance. Our results show that in PEPCK-bGH transgenic mice, the alterations detected in InsR number and insulin-induced autophosphorylation of the InsRs are secondary to hyperinsulinemia and not related to the high levels of $\mathrm{GH}$. Furthermore, we could not detect any influence of InsR Ser/Thr phosphorylation on InsR autophosphorylation in this in vivo model.

\section{Acknowledgements}

F P Dominici and A Balbis contributed equally to this paper and should both be considered as first authors.

These studies were supported by NIH via grants DK42137 and HD20001 (A B), and grants from UBA, Fundación Antorchas and CONICET (D T). D T is a career investigator from CONICET. We thank Dr A F Parlow, the Pituitary Hormones and Antisera Center and NIDDKD for reagents for $\mathrm{mGH}$ and $\mathrm{bGH}$ radioimmunoassays. We wish to thank Dr Marloes Jacob for sharing some of the transgenic-STZ mice used in this study. Transgenic mice were derived from animals kindly provided by Drs T E Wagner and J S Yun.

\section{References}

Balbis A, Dellacha JM, Calandra RS, Bartke A \& Turyn D 1992 Down regulation of masked and unmasked insulin receptors in the liver of transgenic mice expressing bovine growth hormone gene. Life Sciences $\mathbf{5 1}$ 771-778.

Balbis A, Bartke A \& Turyn D 1996 Overexpression of bovine growth hormone in transgenic mice is associated with changes in hepatic insulin receptors and in their kinase activity. Life Sciences $\mathbf{5 9}$ 1363-1371.

Bisbis S, Bailbe D, Tormo MA, Picarel-Blanchot F, Derovet M, Simon J \& Portha B 1993 Insulin resistance in the GK rat: decreased receptor number but normal kinase activity in liver. American Journal of Physiology 265 E807-E813.

Bradford MM 1976 A rapid and sensitive method for the quantitation of microgram quantities of protein utilizing the principle of protein-dye binding. Analytical Biochemistry 72 248-254.

Coghlan MP \& Siddle K 1993 Phorbol esters induce insulin receptor phosphorylation in transfected fibroblasts without affecting tyrosine kinase activity. Biochemical and Biophysical Research Communications 193 371-377.

Coghlan MP, Pillay TS, Tavare JM \& Siddle K 1994 Site-specific anti-phosphopeptide antibodies: use in assessing insulin receptor serine/threonine phosphorylation state and identification of serine-1327 as a novel site of phorbol ester-induced phosphorylation. Biochemical Journal 303 893-899.

Davidson MB 1987 Effect of growth hormone on carbohydrate and lipid metabolism. Endocrine Reviews 8 115-131.

Debant A, Guerre-Millo M, Le-Marchand-Brustel Y, Freychet P, Lavau M \& Van Obberghem E 1987 Insulin receptor kinase is hyperresponsive in adipocytes of young obese Zucker rats. American Journal of Physiology 252 E273-E278. 
Dunaif A, Xia J, Book CB, Schenker E \& Tang Z 1995 Excessive insulin receptor phosphorylation in cultured fibroblasts and in skeletal muscle. Journal of Clinical Investigation 96 801-810.

Goren HJ, White MF \& Kahn CR 1987 Separate domains of the insulin receptor contain sites of autophosphorylation and tyrosine kinase activity. Biochemistry 26 2374-2382.

Hansen IE, Tealikian E, Beaufrere B, Gerich J, Haymond M \& Rizza R 1986 Insulin resistance in acromegaly: defects in both hepatic and extra hepatic insulin action. American Journal of Physiology 250 169-173.

Hepp KD, Langley J, von Funcke HJ, Renner R \& Kemmler W 1975 Increased insulin binding capacity of liver from diabetic Chinese hamsters. Nature 258154.

Kadowaki T, Kasuga M, Akanuma Y, Ezaki O \& Takaku F 1984 Decreased autophosphorylation of the insulin receptor-kinase in streptozotocin-diabetic rats. Journal of Biological Chemistry 259 14208-14216.

Kahn CR 1995 Causes of insulin resistance. Nature 373 384-385.

Kalant N, Ozaki S, Maekubo H, Mitmaker B \& Cohen-Khallas M 1984 Down regulation of insulin binding by human and rat hepatocytes in primary culture: the possible role of insulin internalization and degradation. Endocrinology 114 37-43.

Karasik A, Rothemberg PL, Kazunori Y, White MF \& Kahn CR 1990 Increased protein kinase activity is linked to reduced insulin receptor autophosphorylation in liver of starved rats. Journal of Biological Chemistry 265 10226-10231.

Kellerer M, Coghlan M, Capp E, Mühlhöfer A, Kroder G, Mosthaf L, Galante P, Siddle K \& Häring HU 1995 Mechanism of insulin receptor kinase inhibition in non-insulin dependent diabetes mellitus patients. Phosphorylation of serine 1327 or threonine 1348 is unaltered. Journal of Clinical Investigation 96 6-11.

Laemmli UK 1970 Cleavage of structural proteins during the assembly of the head of bacteriophage T4. Nature 259 680-685.

Lewis RE, Cao L, Perregaux D \& Czech MP 1990 Threonine 1336 of the human insulin receptor is a major target for phosphorylation by protein kinase C. Biochemistry 29 1807-1813.

Lim N, Wijaya E \& Ng F 1994 Stimulation of insulin receptor kinase activity by an amino terminal sequence of human growth hormone. Life Sciences 54 1471-1481.

Lowry OH, Rosebrough NJ, Farr AL \& Randall RJ 1951 Protein measurement with the Folin phenol reagent. Journal of Biological Chemistry 193 265-275.

McGrane MM, de Vente J, Yun J, Bloom J, Park E, Wynshaw-Boris A, Wagner T, Rottman FM \& Hanson RW 1988 Tissue-specific expression and dietary regulation of a chimeric phosphoenolpyruvate carboxykinase/bovine growth hormone gene in transgenic mice. Journal of Biological Chemistry 263 11443-11451.

Martinez C, Molero JC, Ruiz P, Del Arco A, Andrés A \& Carrascosa JM 1995 Impairment of the liver insulin receptor autoactivation cascade at full-term pregnancy in the rat. Biochemical Journal 311 523-529.

Moller DE \& Flier JS 1991 Insulin resistance - mechanisms, syndromes and implications. New England Journal of Medicine 325 938-948.
Pillay TSJ, Whitaker R, Lammers A, Ullrich K \& Siddle 1991 Multisite serine phosphorylation of the insulin and IGF-I receptors in transfected cells. FEBS Letters 288 206-211.

Ruiz P, Pulido JA, Martinez C, Carrascosa JM, Satriustegui J \& Andrés A 1992 Effect of aging on the kinetic characteristics of the insulin receptor autophosphorylation in rat adipocytes. Archives of Biochemistry and Biophysics 296 231-238.

Shemer J, Ota A, Adamo M \& LeRoith D 1988 Insulin-sensitive tyrosine kinase is increased in livers of adult Zucker rats: correction with prolonged fasting. Endocrinology 123 140-148.

Slieker LJ, Roberts EF, Shaw WN \& Johnson WT 1990 Effect of streptozotocin-induced diabetes on insulin-receptor tyrosine kinase activity in obese Zucker rats. Diabetes 39 619-625.

Sotelo AI, Bartke A \& Turyn D 1993 Effects of bovine growth hormone $(\mathrm{GH})$ expression in transgenic mice on serum and pituitary inmunoreactive mouse GH levels and pituitary GH-releasing factor binding sites. Acta Endocrinologica 129 446-452.

Strack V, Stoyanov B, Bossenmaier B, Mosthaf L, Kellerer M \& Häring H-U 1997 Impact of mutations at different serine residues on the tyrosine kinase activity of the insulin receptor. Biochemical and Biophysical Research Communications 239 235-239.

Takayama SMF, White MF, Lauris V \& Kahn CR 1984 Phorbol ester modulate insulin receptor phosphorylation and insulin action in cultured hepatoma cells. Proceedings of the National Academy of Sciences of the USA 81 7797-7801.

Takayama SMF, White MF \& Kahn RC 1988 Phorbol ester-induced serine phosphorylation of the insulin receptor decreases its tyrosine kinase activity. Journal of Biological Chemistry 263 3440-3447.

Tavare JM, Zhang B, Ellis L \& Roth RA 1991 Insulin-stimulated serine and threonine phosphorylation of the human insulin receptor. Journal of Biological Chemistry 266 21804-21809.

Towbin H, Staehelin T \& Gordon J 1979 Electrophoretic transfer of proteins from polyacrylamide gels to nitrocellulose sheets: procedure and some applications. Proceedings of the National Academy of Sciences of the USA 76 4350-4354.

Turyn D, Scacchi GE \& Dellacha JM 1985 Unmasking of insulin receptors in rat submaxillary gland microsomes: effect of high ionic strength, phospholipase $\mathrm{C}$ and S-adenosyl-L-methionine. Biochimica et Biophysica Acta 845 333-342.

Valera A, Rodriguez-Gil JE, Yun JS, McGrane MM, Hanson RW \& Bosch F 1993 Glucose metabolism in transgenic mice containing a chimeric P-enolpyruvate carboxykinase/bovine growth hormone gene. FASEB Journal 7 791-800.

White MF \& Kahn CR 1994 The insulin signalling system. Journal of Biological Chemistry 269 1-4.

Received 9 October 1997

Revised manuscript received 25 March 1998

Accepted 13 May 1998 